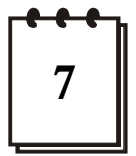

\title{
Sosiologi Kepentingan (Interest) dalam Tindakan Ekonomi
}

\author{
Titik Sumarti ${ }^{1}$
}

\section{Ringkasan}

Sosiologi ekonomi adalah wilayah kajian baru dalam sosiologi yang berusaha mendekatkan ilmu ekonomi dan sosiologi. Sebagai bidang studi baru dalam sosiologi, disiplin ini berupaya untuk terus mengembangkan telaah-telaah baru. Salah satu isyu penting yang menjadi perhatian pemerhati sosiologi ekonomi adalah interest (kepentingan), yang dianggap sebagai konsep penting penggerak tindakan atau perilaku seseorang actor dalam tradisi sosiologi weberian. Tulisan ini mencoba mengkaji isyu/konsep kepentingan serta implikasi sosiologisnya dalam perilaku ekonomi kontemporer.

Katakunci: Kepentingan (interest), sosiologi ekonomi, tindakan ekonomi, weberian

\section{Pendahuluan}

Sosiologi ekonomi secara sederhana didefinisikan sebagai penerapan tradisi sosiologi dalam upaya menjelaskan fenomena ekonomi. Salah satu perbedaan mendasar dengan teori ekonomi konvensional adalah bahwa pumpunan studi sosiologi pada peranan relasi sosial dan kelembagaan sosial dalam tindakan ekonomi. Dengan kata lain, pola-pola interaksi sosial dan kelembagaan, yang dibentuk oleh manusia dalam upaya memenuhi kebutuhan hidup dan memperoleh keuntungan, merupakan subyek utama kajian sosiologi ekonomi.

Saat menulis buku tentang "Prinsip-prinsip Sosiologi Ekonomi", Swedberg memiliki dua tujuan utama yaitu: (1) memperkenalkan suatu pendekatan baru dalam sosiologi ekonomi, dan (2) mengemukakan konsep-konsep, idea (gagasan-gagasan), dan temuan-temuan utama pendekatan tersebut. Bidang kajian pendekatan baru dalam sosiologi ekonomi ini bukan lagi pada impak relasi sosial pada tindakan ekonomi, melainkan pada pertimbanganpertimbangan kepentingan yang menentukan tindakan ekonomi. Analisa pada level kepentingan ini dimulai dengan penempatan kepentingan-kepentingan manusia (dalam kasus Weber, kepentingan agama dan ekonomi), dan mengkaji kekuatan-kekuatan sosial yang mempengaruhi kepentingan serta konsekuensinya. Analisa ini dianggap lebih tajam dan realistis dibanding analisa pada level relasi sosial maupun kelembagaan.

Dalam pendekatan baru ini, Swedberg memperkenalkan konsep sosiologi kepentingan. Dengan merujuk pada sosiologi religi yang dikemukakan oleh Weber, religi sebagai suatu kepentingan merupakan metafora (kiasan) dari

\footnotetext{
1 Dosen mata kuliah Antropologi Ekonomi (S2/S3) serta mata kuliah Program Studi Sosiologi Pedesaan Departemen Komunikasi dan Pengembangan Masyarakat IPB. Saat ini mengemban tugas sebagai
} 
tindakan-tindakan manusia yang berlangsung sepanjang perjalanan-perjalanan hidup yang berbeda, pun ketika hal itu diinspirasikan melalui motivasimotivasi yang serupa. Menurut Weber, kepentingan mendorong tindakan manusia, yaitu dimana cara pandang aktor terhadap dunia kehidupannya (termasuk didalamnya kepentingan yang mereka miliki) yang akan menentukan arah tindakan yang akan diambil sang aktor. Selain Weber, Swedberg juga mengemukakan karya penulis lain seperti Alexis de Tocqueville, James Coleman, Pierre Bourdieu. Pemikir seperti David Hume, Adam Smith dan John Stuart Mill, mengungkapkan bahwa kepentingan menjadi penjelas utama dalam teori perilaku sosial. Menurut analisa mereka, ada beragam tipe kepentingan - tidak hanya kepentingan ekonomi. Kepentingan dapat bertentangan satu sama lain, menghalangi maupun memperkuat satu sama lain.

Thesis utama buku ini adalah bahwa untuk dapat menghasilkan pendekatan sosiologi ekonomi yang ampuh maka diperlukan kombinasi analisa kepentingan ekonomi dengan analisa relasi sosial. Dalam pendekatan ini, maka kelembagaan dapat dipahami sebagai konfigurasi yang khas antara kepentingan dan relasi sosial. Cara Swedberg dalam mengemukakan konsep-konsep dan temuan-temuan kunci dapat ditelusuri melalui pengorganisasian buku yang ditulisnya, yaitu: pertama, mendiskusikan sejarah sosiologi ekonomi: konsep dan temuan pokok (bab 1 dan 2); kedua, diskusi tentang kapitalisme, perusahaan, dan pasar (bab 3, 4, 5 dan 6); ketiga, peranan politik dan hukum (bab 7 dan 8); keempat, presentasi tentang hubungan antara kebudayaan (termasuk konsumsi) dan ekonomi, dan antara gender serta ekonomi (bab 9, 10 dan 11); kelima, penyampaian beragam pertanyaan, sebagai agenda sosiologi ekonomi saat ini, termasuk pertanyaan apakah sosiologi ekonomi harus menjadi sebuah ilmu kebijakan.

Telaah buku ini dilakukan dalam upaya menjelaskan konsep kepentingan sebagai sebuah pendekatan atau kerangka konseptual. Penjelasan tersebut dengan mengikuti sistematika sebagai berikut: catatan perkembangan historis, pumpunan studi, pernyataan ulang kerangka pemikiran dan konsep dasar, asumsi dasar, hasil pada studi tindakan ekonomi, orientasi nilai penganutnya, evaluasi atas sumbangan studi.

\section{Kerangka Konseptual Kepentingan}

2.1. Catatan perkembangan historis

Peranan konsep kepentingan dalam analisa sosial (halaman 1-3).

\begin{tabular}{|c|c|ll|}
\hline Masa-periode & Pendekatan & \multicolumn{3}{|c|}{ Konsep Kepentingan } \\
\hline Middle ages, Barat & Ekonomi dan Politik & $\begin{array}{l}\text { "tingkat kepentingan" (dalam hukum Roma) } \\
\text { Peribahasa "Kepentingan tidak akan } \\
\text { berbohong" menjadi popular }\end{array}$ \\
\hline $\begin{array}{c}\text { Abad 17, filosofi } \\
\text { moral Perancis }\end{array}$ & $\begin{array}{c}\text { Psikologis (La } \\
\text { Rochefoucauld dan } \\
\text { Pascal) }\end{array}$ & $\begin{array}{l}\text { Peribahasa "Kepentingan pribadi membutakan } \\
\text { beberapa orang, tetapi dapat menjadi } \\
\text { pencerahan bagi yang lain" }\end{array}$ \\
\hline Abad 18 & $\begin{array}{c}\text { Filosofi (David Hume } \\
\text { dan Helvetius) }\end{array}$ & $\begin{array}{l}\text { Kepentingan bersifat tetap, sekali untuk } \\
\text { selamanya, dan merupakan produk sifat }\end{array}$ \\
\hline
\end{tabular}




\begin{tabular}{|c|c|c|}
\hline & & $\begin{array}{l}\text { manusia (biologis). } \\
\text { "dunia fisik diatur melalui hukum gerakan, } \\
\text { dan moral secara universal diatur melalui } \\
\text { hukum kepentingan" }\end{array}$ \\
\hline Abad 19 & Ekonomi & $\begin{array}{l}\text { "Kepentingan ekonomi" (utilitas dan preferensi) } \\
\text { sebagai bagian homo economicus. }\end{array}$ \\
\hline \multirow[t]{2}{*}{$\begin{array}{l}\text { Akhir abad } 19 \text { dan } \\
\text { awal abad } 20\end{array}$} & $\begin{array}{l}\text { Sosiologi (Weber dan } \\
\text { Simmel) }\end{array}$ & $\begin{array}{l}\text { "Bukan ide (gagasan), tetapi kepentingan } \\
\text { materi dan ideal, yang mengatur secara } \\
\text { langsung tindakan manusia. Tidak jarang pula } \\
\text { "image dunia" yang diciptakan melalui ide-ide, } \\
\text { merupakan penentu tindakan yang didorong } \\
\text { melalui dinamika kepentingan. }\end{array}$ \\
\hline & Swedberg & $\begin{array}{l}\text { Mirip dengan Weber. Kepentingan mendorong } \\
\text { tindakan manusia tetapi elemen sosial (dalam } \\
\text { Weber, agama) menentukan ekspresi dan arah } \\
\text { tindakan apa yang akan diambil. Kepentingan } \\
\text { dapat berbentuk materi maupun ideal (agama, } \\
\text { politik dsb). Seluruh kepentingan menjadi } \\
\text { sosial dalam dua cara: (1) menjadi bagian } \\
\text { masyarakat dimana individu dilahirkan, dan } \\
\text { (2) individu mempertimbangkan aktor lain } \\
\text { ketika mencoba merealisasikan kepentingan } \\
\text { mereka. }\end{array}$ \\
\hline
\end{tabular}

\subsection{Pumpunan studi}

Pumpunan studi adalah pada tindakan ekonomi sebagai suatu tindakan sosial. Tindakan ekonomi didorong oleh kepentingan. Kepentingan didefinisikan secara sosial.

2.3. Pernyataan ulang kerangka pemikiran dan konsep dasar (halaman 291-297) Konsep kepentingan merupakan konsep pokok dalam ilmu sosial, dan karenanya mutlak dibutuhkan dalam sosiologi ekonomi. Kepentingan yang membuat orang mengambil tindakan. Kepentingan mampu mensuplai energi (kekuatan) dan membuat orang bangkit dari tidur dini hari serta bekerja keras sepanjang hari. Jika dikombinasikan (digabungkan) dengan kepentingan orang lain, akan menjadi suatu kekuatan yang cukup besar yang mampu menggerakkan dan menciptakan masyarakat baru.

Analisa kepentingan membantu untuk menjelaskan konflik, yang muncul ketika terjadi benturan kepentingan. Konflik tersebut dapat berlangsung dalam pikiran seseorang, antar individu, kelompok, dan masyarakat. Tetapi kepentingan tidak hanya berbenturan dan menggerakkan aktor, kepentingan juga bisa menghalangi satu sama lain, menguatkan satu sama lain, atau melumpuhkan sang aktor, misalnya pembentukan beberapa religi atau politik yang mendukung tradisi. Konsep kepentingan merupakan suatu alat analisa yang fleksibel.

Menggunakan konsep kepentingan berarti mengubah pusat analisa dari kekuatan di permukaan ke daerah kekuatan yang lebih mendalam yang memiliki impak penting pada tindakan sosial. Analisa Weber dalam The Protestan Ethic merupakan paradigma dalam hal upayanya untuk menganalisa 
apa yang membuat orang merubah perilaku mereka secara mendasar yang menciptakan suatu mentalitas rasionalistis baru secara menyeluruh.

Menggunakan konsep kepentingan juga dapat membantu memberikan tempat seimbang pada peranan subyektivitas dan kebudayaan dalam analisa perilaku ekonomi. Sesungguhnya tidak bisa dilupakan - kepentingan dalam beberapa hal selalu subyektif dan dibentuk melalui kebudayaan - tetapi kepentingan juga bersifat obyektif dalam arti bahwa kepentingan membentuk suatu bagian yang stabil dan kukuh dari realitas sosial. Moralitas negara atau umum, misalnya, bisa melarang aktivitas tertentu tetapi bisa juga membolehkan di tempat lain.

Terdapat upaya mengintegrasikan kepentingan kedalam tipe analisa sosiologi. Pendekatan ini memperhitungkan baik kepentingan maupun relasi sosial menjelaskan bahwa kepentingan didefinisikan dan diekspresikan melalui relasi sosial.

Kepentingan adalah sesuatu yang mendorong tindakan individu-individu pada beberapa tingkatan yang mendasar. Lebih lanjut, kepentingan merupakan fenomena sosial yang intens. Individu lain harus dipertimbangkan ketika seorang aktor berupaya untuk merealisasikan kepentingannya. Hal ini juga merupakan fakta bahwa kepentingan didefinisikan secara sosial. Definisi kepentingan ini cukup luas mencakup beragam tipe kepentingan, tidak hanya kepentingan ekonomi. Konsep kepentingan digunakan untuk menangkap kekuatan pokok yang mendorong perilaku manusia.

\subsection{Asumsi-Asumsi Dasar}

Sama pentingnya dengan memperkenalkan konsep kepentingan ekonomi dalam sosiologi ekonomi, Swedberg mengusulkan untuk menghindari mainstream ekonomi vis a vis kepentingan. Beberapa point yang diusulkan (halaman 4-5):

- Konsep kepentingan yang dimaksud adalah sebagai konsep analitis untuk menganalisa realitas sosial.

- Dalam merealisasikan kepentingannya, aktor mengorientasikan dirinya pada aktor lain dalam beragam cara. Struktur sosial dengan demikian menjadi bagian dari analisa.

- Berbeda dengan ahli ekonomi, dimana hanya ada satu tipe kepentingan (diasumsikan, sepenuhnya dipahami melalui aktor yang memaksimumkan kepentingan ekonomi), maka sosiologi ekonomi bebas untuk menggambarkan tradisi analisa kepentingan. Menurut tradisi ini, ada banyak tipe kepentingan yang berbeda, dan dapat memiliki kombinasi yang berbeda satu sama lain.

- Dalam ekonomi, konsep kepentingan biasanya digunakan sebagai satu pengulangan. Hal ini harus dihindari dalam analisa sosiologi kepentingan. 
2.5. Hasil atau dampaknya pada studi tindakan ekonomi

Keuntungan menggunakan konsep kepentingan dalam analisa sosiologi ekonomi (halaman 4):

- Adanya kesempatan untuk memahami kekuatan yang mendasari tindakan. Apa yang mendorong orang maupun perusahaan swasta bekerja setiap hari, pertama-tama adalah kepentingan ekonomi. Konsep kekuasaan dan sumber-sumber kekuasaan memiliki fenomena yang sama dengan konsep kepentingan, tetapi tidak seluruhnya.

- Dapat menjelaskan mengapa satu pola tindakan diambil daripada pola lainnya. Beberapa alternative mungkin sangat menarik aktor, sesuai kepentingannya, atau bahkan tak ada kepentingan sama sekali. Dengan kata lain, kepentingan mempengaruhi keputusan sang aktor, atau pilihannya.

- Munculnya suatu dinamika dalam analisis, yang berbeda dengan analisis tindakan karena didorong interaksi sosial. Kepentingan ekonomi, sedikit mirip dengan kepentingan seksual, sering ditemukan dimana saja berada di bagian belakang menunggu kesempatan untuk direalisasikan. Jika dilarang, misalnya akan muncul pasar gelap (black market).

- Dapat membangun keterkaitan, tidak hanya dengan sisi biologi dari keberadaan manusia, tetapi juga lingkungannya. Kepentingan ekonomi, berakar pada kebutuhan manusia dan ketergantungannya dengan lingkungan.

\subsection{Orientasi nilai penganutnya}

Kepentingan merupakan kekuatan pokok yang mendorong tindakan ekonomi. Kepentingan bisa berbenturan, saling menghalangi maupun saling menguatkan, dan mendorong maupun melumpuhkan aktor.

2.7. Evaluasi atas sumbangan: kontradiksi dan kekurangan

Analisa yang menggambarkan kepentingan memiliki resiko tautology, yaitu mencoba untuk menjelaskan segala sesuatu sebagai hasil beberapa kepentingan. Analisa kepentingan juga memiliki tendensi untuk mereduksi segala sesuatu dalam suatu cara mekanik untuk beberapa kepentingan.

Perlu juga dipertimbangkan hubungan antara kepentingan dan motivasi, yang dianggap setara dalam psikologi.

\section{Perbandingan Sosiologi Tindakan Ekonomi: Weber, Granovetter, Coleman dan Swedberg}

Weber mengemukakan bahwa analisa tindakan ekonomi tidak hanya mengkover "fenomena ekonomi", tetapi juga "fenomena yang relevan secara 
ekonomi", dan "fenomena yang dikondisikan secara ekonomi" (dalam Swedberg, 2003):

1. Fenomena ekonomi terdiri dari norma-norma ekonomi dan kelembagaan ekonomi yang terbentuk untuk memenuhi tujuan ekonomi (misalnya, perbankan) - dipelajari melalui teori ekonomi

2. Fenomena yang relevan secara ekonomi adalah fenomena non ekonomi yang memberi impak pada fenomena ekonomi (misalnya ascetic Protestantism, sebuah analisa dalam The Protestant Ethic) - dipelajari melalui sejarah ekonomi maupun sosiologi ekonomi

3. Fenomena yang dikondisikan secara ekonomi adalah fenomena pada tingkat tertentu dipengaruhi oleh fenomena ekonomi (misalnya tipe religi yang cenderung diadopsi sebagian tergantung pada jenis pekerjaan yang dilakukan anggotanya) - dipelajari melalui sejarah ekonomi maupun sosiologi ekonomi

Analisis tindakan ekonomi, menurut Weber (dalam Swedberg, 1998), berbedabeda menurut disiplin ilmu yang digunakan:

A. Economic Theory

(economic action)

Actor A

Utility

Interest

(mainly material)

B. Sociologi Theory

(social action)

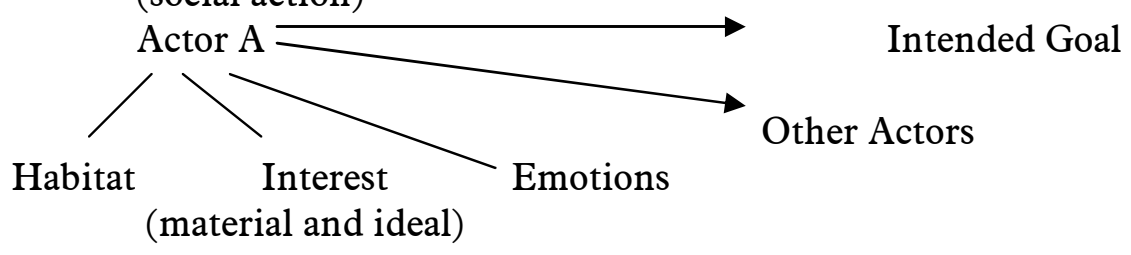

(material and ideal)

C. Economy Sociology

(economic social action)

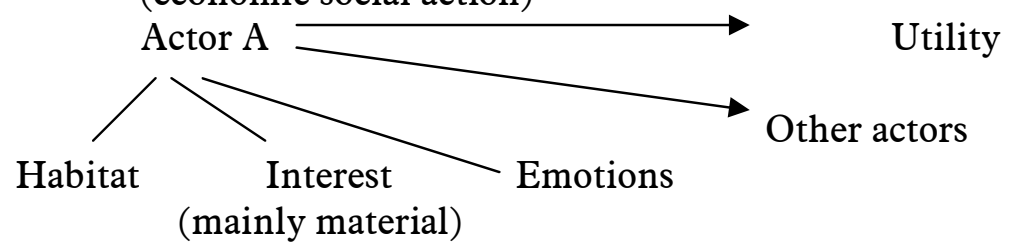

Ahli ekonomi mempelajari tindakan ekonomi murni, yaitu suatu tindakan yang secara eksklusive didorong oleh kepentingan ekonomi - atau "harapan terhadap 
kegunaan". Sedangkan ahli sosiologi ekonomi mempelajari tindakan ekonomi yang berorientasi sosial, yaitu tindakan yang didorong oleh kepentingan ekonomi dan diorientasikan pada aktor lain. Tindakan ekonomi sosial tidak hanya didorong oleh kepentingan ekonomi tetapi juga oleh tradisi maupun emosi.

Secara garis besar Weber membedakan analisa sosiologi tindakan ekonomi dari analisa ekonomi dengan mengajukan 3 (tiga) unsur:

1. Tindakan ekonomi adalah sebuah tindakan sosial

2. Tindakan ekonomi selalu melibatkan makna

3. Tindakan ekonomi selalu memperhatikan kekuasaan

Terdapat tiga tipe tindakan ekonomi yang berbeda: yang diinspirasikan oleh custom (termasuk habit), convention (norma), dan interest. Tindakan yang ditentukan oleh kepentingan didefinisikan sebagai tindakan instrumental dan berorientasi pada harapan yang identik. Dengan kata lain, tindakan ini mensyaratkan setting sosial dimana aktor lain berpikir dengan cara instrumental yang sama. Misalnya, dalam pasar modern, seorang aktor adalah rasional instrumental dan menganggap orang lain sama rasionalnya.

Weber juga menekankan bahwa kepentingan selalu diterima secara subyektif. "Kepentingan aktor adalah apa yang mereka sendiri sadari". Jika beberapa individu berperilaku dalam suatu perilaku instrumental, dalam kaitan dengan kepentingan individu mereka, dapat menghasilkan pola perilaku kolektif yang lebih stabil daripada jika norma diterapkan oleh suatu lembaga otoritas.

Tindakan ekonomi dua aktor yang berorientasi satu sama lain, membentuk hubungan ekonomi. Hubungan tersebut dapat mengambil beragam ekspresi, mencakup konflik, kompetisi, dan upaya untuk menguasai seseorang (kekuasaan). Jika dua atau lebih aktor diikat bersama oleh rasa memiliki, hubungan membentuk "komunal", tetapi jika diikat bersama oleh kepentingan, hubungan membentuk "asosiasi". Kekayaan, misalnya merupakan bentuk khusus hubungan ekonomi yang tertutup.

Organisasi ekonomi merupakan bentuk lain hubungan ekonomi tertutup. Weber memperkenalkan tipologi organisasi, dari organisasi ekonomi murni sampai pada organisasi yang tugas pokoknya mengatur hubungan ekonomi (misalnya trade union). Pasar, seperti fenomena ekonomi lainnya, berpusat pada konflik kepentingan ekonomi - terutama antara sellers dan buyers. Dalam pasar terdapat kompetisi dan pertukaran. Kompetisi muncul untuk melihat siapa yang akan menjadi penjual terakhir dan pembeli terakhir (perjuangan antar competitor), setelah itu baru berlangsung pertukaran (perjuangan melalui pertukaran). Hanya capitalism rational yang ada dalam pasar modern. Sebutan "capitalism politik adalah kunci pembentukan keuntungan" ini adalah bahwa otoritas politik mendukung kepentingan ekonomi swasta. Kapitalism komersial tradisional terdiri dari perdagangan skala kecil, pedagang. Kapitalism rasional hanya muncul di Barat.

Granovetter memperkenalkan konsep "embeddedness" dalam menganalisa tindakan ekonomi. Tindakan ekonomi adalah tindakan yang sangat melekat 
dalam jaringan hubungan sosial interpersonal dari para aktor. Terdapat tiga propisisi utama yang diajukan dalam sosiologi ekonomi baru (Granovetter dan Swedberg, 1992):

1. Tindakan ekonomi adalah suatu bentuk tindakan sosial

2. Tindakan ekonomi disituasikan secara sosial

3. Institusi-institusi ekonomi dikonstruksikan secara sosial

Kontribusi sosiologi ekonomi baru dalam analisa tindakan ekonomi adalah pada pendekatan jaringan, teori organisasi, dan sosiologi kebudayaan sebagai alat analisa.

Dari sudut pandang kepentingan, argumen Granovetter dapat dibedakan antara level mikro dan level kelembagaan (Swedberg, halaman 37). Pada tingkat kelembagaan, kelembagaan ekonomi dibahas dalam kaitan dengan mobilisasi sumber-sumber untuk tindakan kolektif - suatu posisi yang dikenal baik dalam analisa kepentingan secara sosiologi. Di tingkat mikro, granovetter berpendapat berbeda dengan ekonom dalam hal kepentingan. Menurut Granovetter, "Ada pertimbangan interaksi manusia yang membatasi penjelasan terhadap kepentingan individu", ia mencatat" lebih abstrak dari aspek mendasar hubungan yang dicirikan ekonomi maupun tindakan lainnya". Granovetter menambahkan - bahwa tindakan ekonomi tidak pernah sepenuhnya (100 persen) bersifat ekonomi tetapi selalu mencakup elemen non ekonomi. Seluruh tindakan sosial, termasuk tindakan ekonomi, pada tingkat tertentu selalu dipengaruhi oleh "motivasi yang berpusat manusia" seperti "sosiabilitas, dukungan, status dan kekuasaan". Pada tingkat mikro, tindakan ekonomi tidak pernah secara eksklusif diinspirasikan oleh kepentingan ekonomi - segera setelah aktor berinteraksi dengan aktor lain, kepentingan lain juga mulai mempengaruhi, yaitu kepentingan sosial.

Sumbangan sosiologi ekonomi baru lainnya datang dari Coleman yang memperkenalkan sosiologi berbasis kepentingan. Coleman mengemukakan bahwa ahli ekonomi telah gagal memperkenalkan relasi sosial dalam analisa mereka. "cara-cara utama teori ekonomi bergerak dari tingkat mikro aktor tunggal ke tingkat makro yang melibatkan banyak aktor adalah melalui konsep "agent representative". Kumpulan para aktor secara sederhana tidak sesuai dengan fenomena seperti trust, sementara trust merupakan suatu hubungan antara dua aktor". Coleman menggunakan tiga subyek untuk menjelaskan hal tersebut: trust, pasar, dan perusahaan.

Beberapa pokok pikiran Coleman:

1. Dalam tindakan ekonomi tidak cukup membahas aktor dan kepentingannya, penting pula dibahas "sumberdaya" dan "kontrol" yang dimiliki. Jika seorang aktor memiliki kepentingan terhadap aktor lain, kedua aktor tersebut akan berinteraksi.

2. Analisa kepercayaan (trust). Coleman mencirikan trust sebagai suatu pertaruhan dengan kesadaran. Anda mengkalkulasi apa yang anda peroleh 
dan kehilangan bila mempercayai seseorang, dan dalam situasi tersebut anda terus dan mempercayai orang tersebut.

3. Analisa modal sosial. Modal sosial didefinisikan Coleman sebagai adanya relasi sosial yang dapat membantu individu ketika mencoba untuk merealisasikan kepentingannya. Suatu perusahaan merepresentasikan, misalnya, suatu bentuk modal sosial.

4. Kemampuan perusahaan - sekali orang menciptakannya untuk merealisasikan kepentingannya - untuk membangun kepentingannya sendiri. Bagi Coleman, perusahaan merupakan suatu penemuan sosial yang mendasar.

Dari tulisan dapat dikemukakan beberapa proposisi yang ditawarkan dalam pendekatan sosiologi ekonomi baru:

1. Tindakan ekonomi didorong oleh suatu kepentingan sebagai kekuatan yang mendasar

2. Kepentingan merupakan fenomena sosial yang didefinisikan secara sosial

3. Kepentingan direalisasikan melalui relasi sosial

\section{Konsep Kepentingan dalam Fenomena Ekonomi}

Kapitalisme: sebuah pengorganisasian sosial seluruh aktivitas ekonomi

Kapitalisme sebagai organisasi ekonomi dalam arti luas, dengan menggunakan analisa kepentingan, dapat dipandang sebagai sebuah jaringan besar dari kepentingan ekonomi dan kepentingan lainnya, yang berhubungan dalam beragam hal melalui interaksi sosial dan struktur sosial.

Definisi umum kapitalisme adalah sebuah organisasi kepentingan-kepentingan ekonomi yang mengarah pada "keuntungan murni dan pengembalian keuntungan" (Weber), M-C-M (uang, komoditi, uang dan nilai tambah)(Marx), dan pemilikan pribadi merupakan prakondisi bagi kapitalisme.

Aktivitas ekonomi mencakup produksi, distribusi dan pertukaran. Proses ekonomi dimulai dari produksi, dan diikuti dengan distribusi dan konsumsi. Mengacu Polanyi, distribusi sebagai cara-cara pengorganisasian ekonomi, memiliki tiga bentuk: redistribusi, resiprositas, dan pertukaran. Redistribusi digunakan dalam ekonomi yang didominasi negara, dan apa yang mendorong produksi adalah kebutuhan untuk konsumsi. Resiprositas digunakan dalam ekonomi berbasis keluarga atau kekerabatan, dan apa yang mendorong produksi adalah juga kebutuhan untuk konsumsi. Pertukaran, secara langsung berhubungan dengan keberadaan pasar, dan mengarah pada kapitalisme. Alasan untuk berproduksi bukan hanya didorong oleh kebutuhan konsumsi tetapi juga keinginan untuk mendapat keuntungan. Mengapa aktor mau terlibat dalam pertukaran? Suatu pertukaran dianggap efisien, bila keuntungan kedua aktor melebihi kerugian yang ditimbulkan, dan keuntungan sosial melebihi kerugian 
sosialnya. Dengan kata lain, kapitalisme berkembang karena kepentingan konsumsi dan keuntungan.

Dalam sosiologi ekonomi, model dasar kapitalisme tersebut perlu dikembangkan. Produksi, dapat dibagi menjadi: tanah, tenaga kerja, modal, teknologi, dan "organisasi" (Marshall), serta mempertimbangkan aspek kebudayaan, kelembagaan politik (termasuk system hukum). Setiap faktor bisa memfasilitasi proses pembentukan keuntungan, bisa juga menghalanginya.

a. Proses ekonomi secara umum

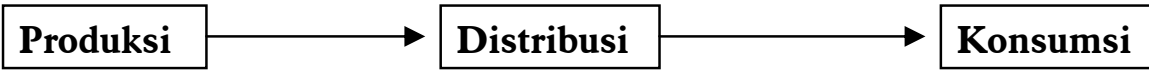

b. Proses ekonomi dimana distribusi mengambil bentuk pertukaran

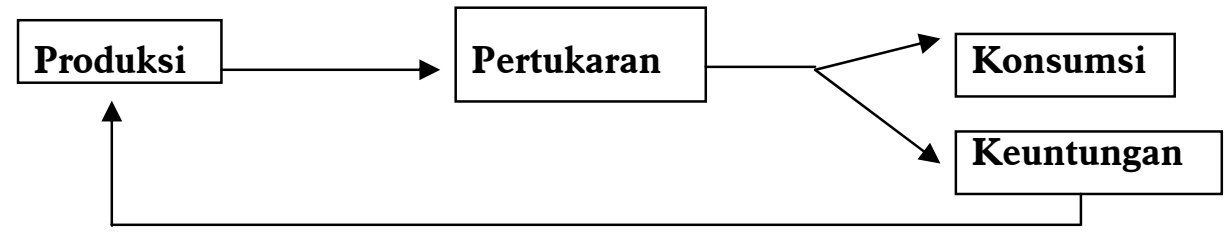

Tindakan pembentukan keuntungan dengan suatu orientasi kapitalistik dapat mengambil sejumlah bentuk yang berbeda secara kualitatif, yang dapat ditipekan secara sosiologi. Menurut Weber, bentuk kapitalisme rasional (terutama terdiri dari keuangan yang lebih maju, produksi yang kontinue, dan adanya penjual dan pembeli tetap dalam suatu pasar bebas). Sementara kapitalisme politik mencakup kasus dimana keuntungan dibentuk oleh negara, melalui kontak dengan negara, atau di bawah proteksi langsung dari negara. Kapitalisme komersial tradisional terdiri dari kegiatan perdagangan barang dan uang dalam skala kecil.

Kapitalisme rasional bisa menjadi dinamis adalah karena adanya perputaran keuntungan untuk investasi kembali dalam produksi. Ketiga tipe kapitalisme dari Weber menyadarkan adanya suatu mekanisme, dan dimana kedua tipe kapitalisme (politik dan komersial tradisional) tidak pernah sukses mengembangkan suatu perputaran feedback yang berfungsi dengan baik.

\section{Penutup}

Sejajar dengan Weber, Granovetter dan Coleman, maka Swedberg berpendapat bahwa tindakan ekonomi merupakan hasil dari proses yang dilakukan individu 
dalam proses relasi sosial yang sedang berlangsung. Sebagai sebuah tindakan sosial, maka tindakan ekonomi selalu melibatkan makna dan memperhatikan kekuasaan (sumbangan Weber), dan melekat dalam jaringan hubungan interpersonal antar aktor (sumbangan Granovetter), serta didorong oleh kepentingan sebagai kekuatan mendasar yang didefinisikan secara sosial (sumbangan Swedberg). Dalam analisa kepentingan, sosiologi ekonomi klasik sudah membahasnya, namun masih sebagai konsep pendukung dari penjelasan tindakan ekonomi dalam masyarakat. Sedangkan Swedberg mencoba mengangkat konsep kepentingan sebagai konsep pokok dalam analisa sosiologi tindakan ekonomi.

\section{Daftar Pustaka}

Morrison, K. 1995. Marx, Durkheim, Weber : Frmation of Modern Social Thought. Sage Publications.

Granovetter, M. and Swedberg, Richard. 1992. The Sociology of Economic Life. Westview Press, Inc.

Smelser, N. J. and Swedberg, Richard. 1994. The Handbook of Economic Sociology. Princeton University Press. New Jersey, US.

Swedberg, R. 2003. Principles of Economic Sociology. Princeton University Press. New Jersey, US.

1996. Economic Sociology. Edwar Elgar Reference Publising Limited. UK Brookfield, US.

1998. Max Weber and the Idea of Economic Sociology. Princeton University Press. New Jersey, US. 